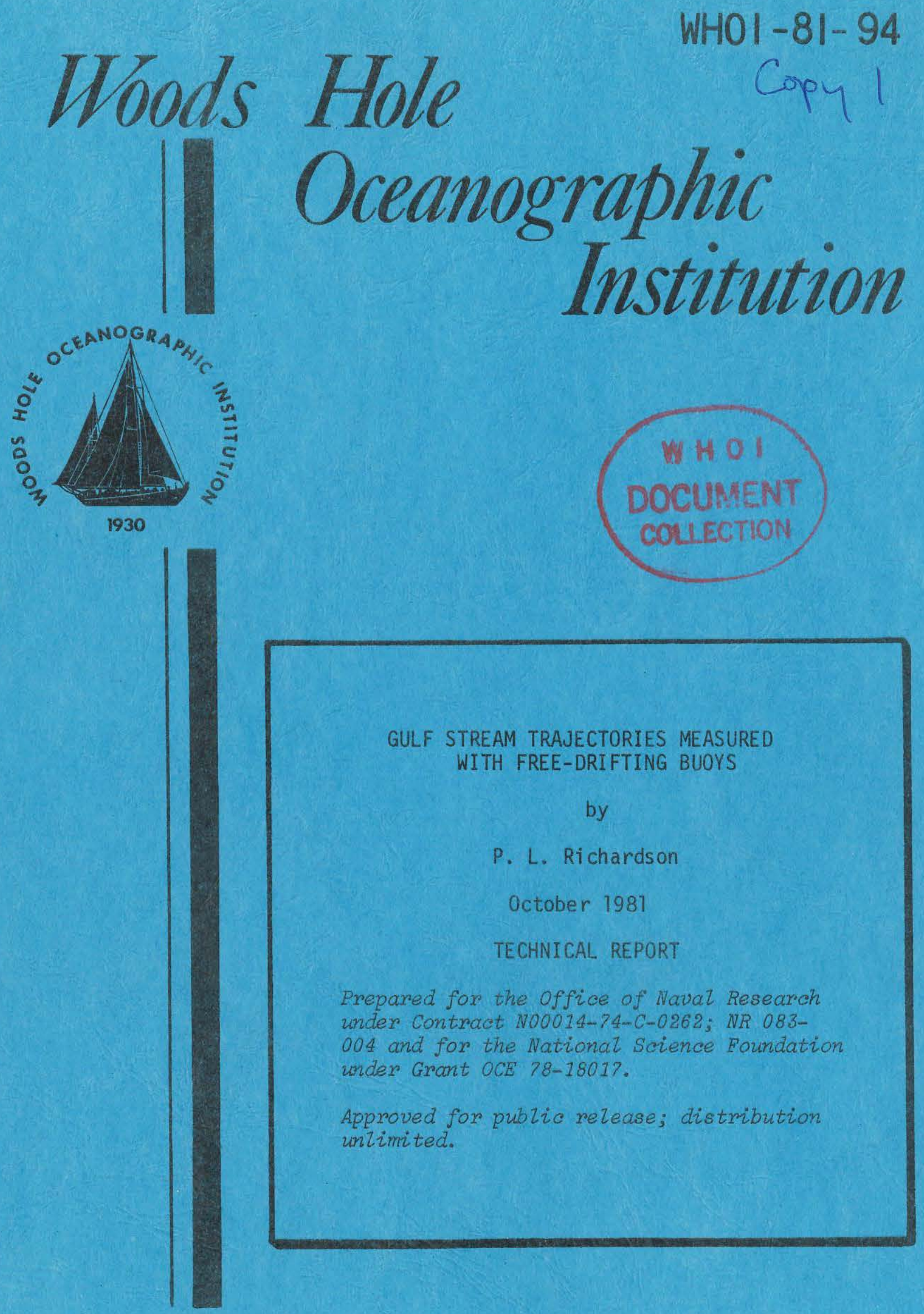

IVOODS HOLE, MASSACHUSETTS 02543 
WHOI $-81-94$

\title{
GULF STREAM TRAJECTORIES MEASURED \\ WITH FREE-DRIFTING BUOYS
}

by

\author{
P. L. Richardson \\ WOODS HOLE OCEANOGRAPHIC INSTITUTION \\ Woods Hole, Massachusetts 02543
}

October 1981

TECHNICAL REPORT

Prepared for the Office of Naval Research under Contract N00014-74-C-0262; NR 083-004 and for the National Science Foundation under Grant OCE 78-18017.

Reproduction in whole or in part is permitted for any purpose of the United States Govermment. In citing this report in a bibliography, the reference given should be to: Joumal of Physical Oceanography 11(7): 999-1010 (July 1981). Approved for public release; distribution unlimited. Approved for Distribution: Valentine Worthington, Chairman Department of Physical Oceanography 
Reprinted from Journal of Physical Oceanography, Vol. 11, No. 7, July 1981

American Meteorological Society

Printed in U. S. A.

\title{
Gulf Stream Trajectories Measured with Free-Drifting Buoys
}

\author{
P. L. RICHARDSON \\ Woods Hole Oceanographic Institution, Woods Hole, MA 02543
}

(Manuscript received 4 December 1980, in final form 30 March 1981)

\begin{abstract}
During 1975-78, 35 free-drifting buoys measured surface currents in the Gulf Stream region. The buoy trajectories trace numerous paths of the Stream and show that the Stream is strongly influenced by the New England Seamounts. This influence is manifested as 1) a quasi-permanent, $100 \mathrm{~km}$, southeastward deflection of the Stream and the frequent occurrence of a ring meander over the seamounts; 2) largeamplitude meanders beginning at the seamounts and extending eastward; and 3) small, $20 \mathrm{~km}$ diameter eddies which appear to be generated locally by individual seamounts.

A chart of the mean temperature field at a depth of $450 \mathrm{~m}$ agrees with several of the patterns seen in the buoy trajectories. West of the seamounts, the mean path of the Gulf Stream is eastward; over the seamounts, the path turns sharply northeastward and the isotherms in the Stream abruptly diverge.
\end{abstract}

\section{Introduction}

Recently, the use of satellites to track free-drifting buoys has made it possible to measure surface currents remotely and rather inexpensively. During the last five years numerous satellite-tracked buoys were used to measure velocities and trajectories in the Gulf Stream system. These provide new information on the path of the Stream, especially its complicated structure near the New England Seamounts. Many buoys displayed a characteristic deflection as they passed over the seamounts; other buoys became trapped over the seamounts and made many loops there. The trajectories suggest that the seamounts strongly influence the mean path of the Gulf Stream and that the seamounts are an important source region of mesoscale eddy motion. The implication of these measurements is that the deeper flow, located at the level of the seamounts themselves, is even more strongly perturbed and may be partially blocked from passing through or over the seamounts.

\section{The buoys}

Most of the buoys were made by Polar Research Laboratory; they had a life of 9-12 months and carried a temperature and drogue sensor. Positions were determined by NASA from the Doppler-shifted radio signal received by the Nimbus $F$ satellite. Typically, two good fixes per day were obtained for each buoy; the rms error of the fixes was estimated to be $1-2 \mathrm{~km}$. Trajectories and velocity along trajectories were computed and plotted by fitting a cubic spline function through the measured positions and by interpolating two positions, velocity, and temperature values per day, evenly spaced in time.

Two types of drogues were commonly used. The first consisted of a $5 \mathrm{~m}$ section of $1 \mathrm{~cm}$ diameter chain attached to a $200 \mathrm{~m}$ section of $3.8 \mathrm{~cm}$ diameter polypropylene line (area $8 \mathrm{~m}^{2}$ ) with a $25 \mathrm{~kg}$ weight attached to the end. The second consisted of the same tether with a window-shade drogue $\left(25 \mathrm{~m}^{2}\right)$ attached to the bottom. The period of time that the drogues actually remained attached to the buoys is unknown. Tensiometers often failed on account of overloading in a "drogue-on" position after a few weeks at sea. It seems probable, based on the performance of buoys we retrieved and on data obtained from recent, more successful drogue sensors, that the drogues usually remained attached to the buoys for a few months and sometimes as long as seven months. Because of uncertainty in the buoy configuration, it is not clear whether the buoys were following currents in the upper $2 \mathrm{~m}$ (the depth of the hull) or in the upper $200 \mathrm{~m}$. It is probably more correct to assume the former. A detailed description of the buoys, drogues and data is given by Richardson et al. (1979).

A comparison of buoy trajectories and wind patterns suggests that as long as the buoys were in swift currents (Gulf Stream, rings, intense eddies) the influence of the wind on the buoy's trajectory was small. However, as the buoys moved into regions of sluggish currents, especially after the drogues had fallen off and in windy conditions, the wind could have determined significant portions of the buoys' trajectories. McNally (1981) found no statistical difference between drogued (to $30 \mathrm{~m}$ ) and undrogued 


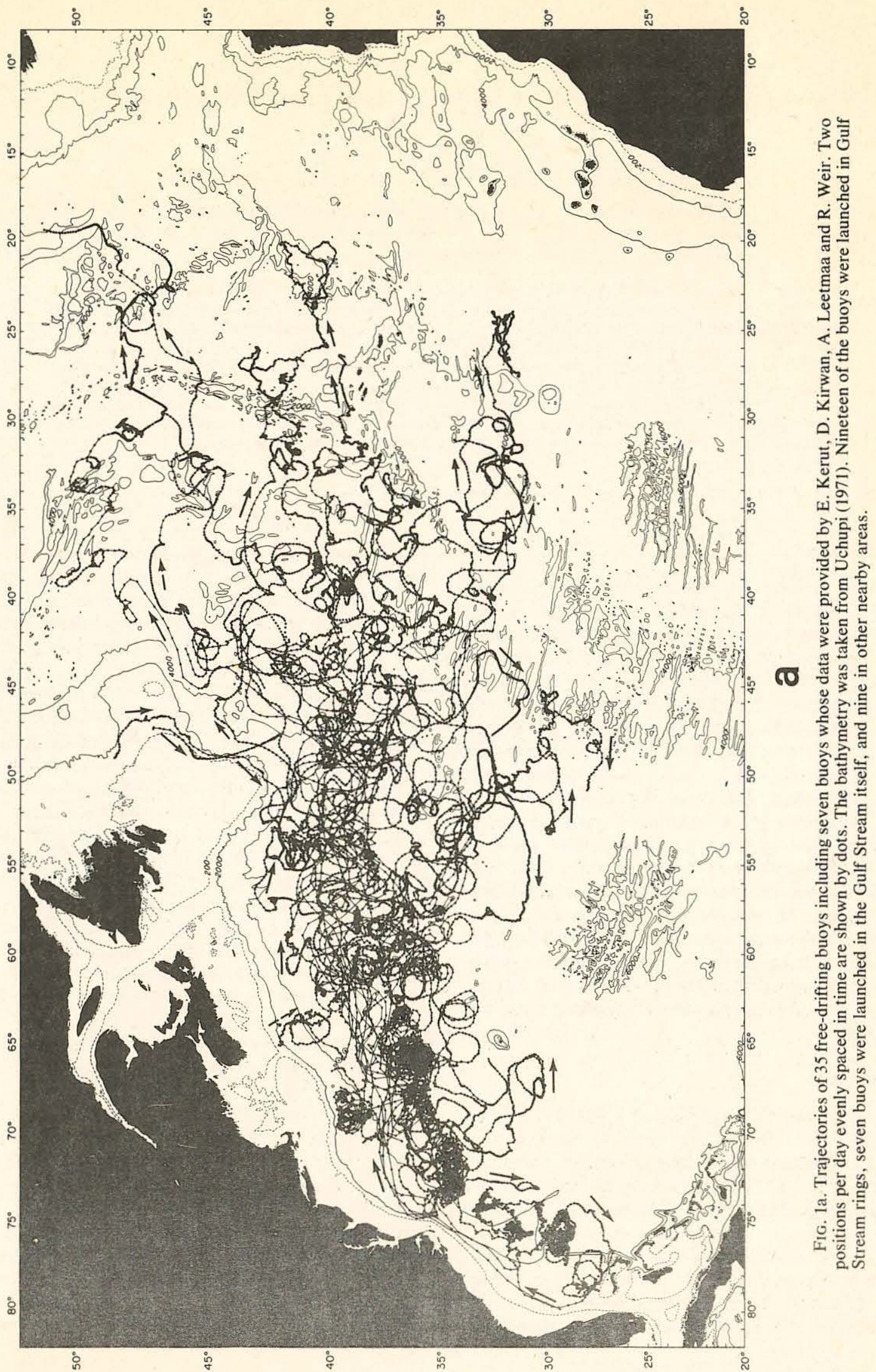




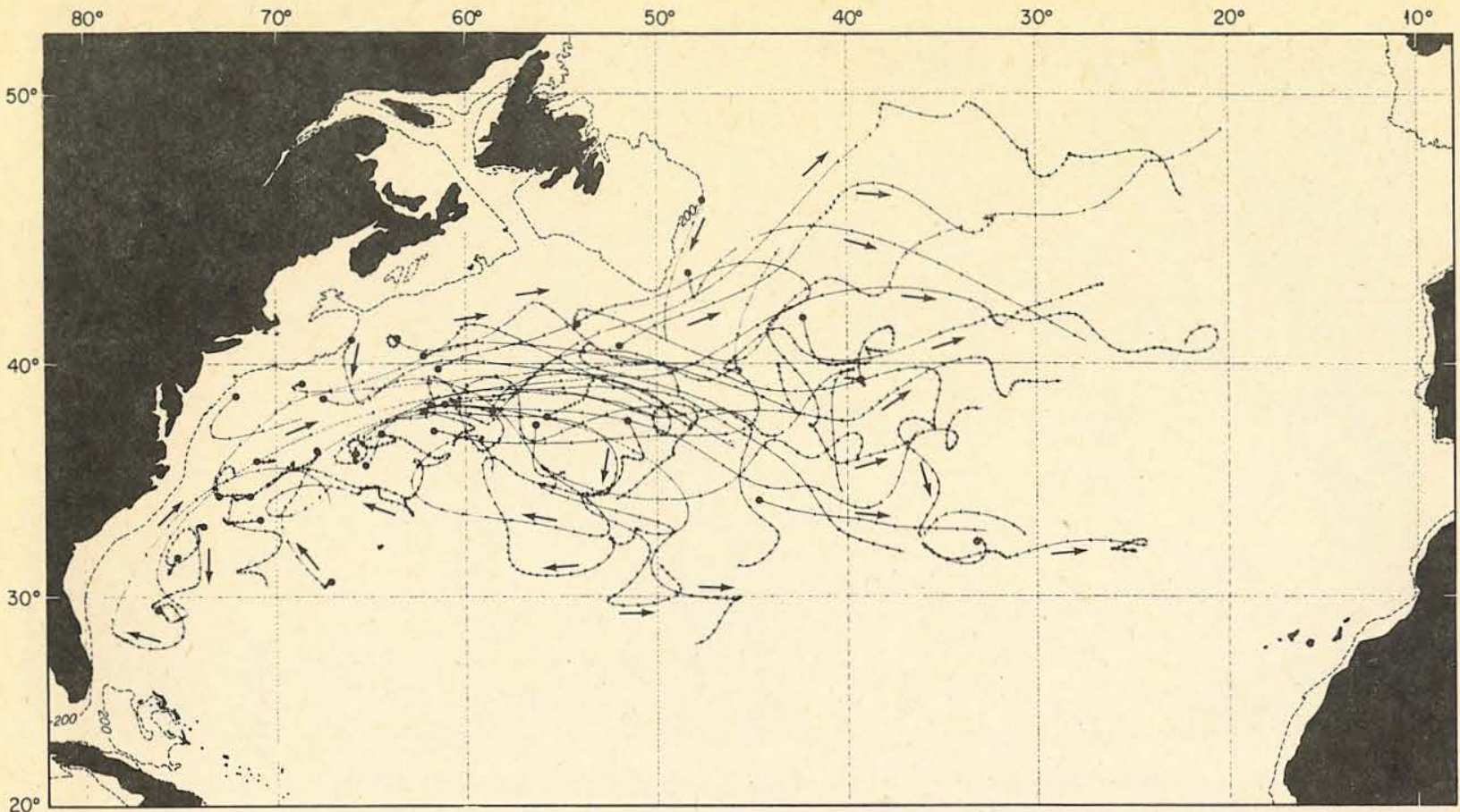

b

FIG. 1b. Buoy trajectories smoothed with a 40-day Gaussian filter to show large-scale motion. Large dots mark the beginning of trajectories, smaller dots are evenly spaced at 5-day intervals.

buoys in the northeastern Pacific, which suggests the slippage of his undrogued buoys was small compared to the wind-driven currents.

\section{The trajectories}

During the period July 1975 - April 1978,35 buoys were launched in the Gulf Stream region. ${ }^{1}$ Nineteen of the buoys were launched in Gulf Stream rings; most of these were in cyclonic rings south of the Stream and were part of the Gulf Stream Ring Experiment. Frequently, rings coalesced with the Stream, either partially or completely, and the buoys were entrained into the Stream and drifted eastward. Seven buoys were launched in the Gulf Stream current itself and nine others in nearby areas; three in the slope water region, three in the Sargasso Sea, two in the Labrador Current, and one near the MidAtlantic Ridge.

Summary plots of all the trajectories (Figs. 1a and 1b) show the area covered by the buoy measurements and also some important characteristics of the currents. (A map of the mean temperature field of this region, which will be discussed later, is shown in

${ }^{1}$ Data from seven of these buoys were provided by E. Kerut $(343,373)$, D. Kirwan (357), A. Leetmaa $(167,1167)$ and R. Weir $(177,271)$. One of the Gulf Stream trajectories has been discussed by Kirwan et al. (1976).
Fig. 2.) The trajectories graphically show different flow regimes in features such as the Gulf Stream, rings, topographic and other mesoscale eddies and in different geographical areas such as the western and eastern basins of the North Atlantic. Many trajectories in rings can be seen between Bermuda and the Gulf Stream. Buoys in rings looped cyclonically with periods ranging from 1.5 to 10 days and translated with rings, generally but not always westward (Richardson, 1980a).

Two areas of the chart show conspicuous loops associated with seamounts. The first of these is along the New England Seamounts which extend from Georges Bank southeastward towards $34^{\circ} \mathrm{N}, 56^{\circ} \mathrm{W}$. The second is over and southwestward of the Corner Rise Seamounts which are centered near $36^{\circ} \mathrm{N}, 52^{\circ} \mathrm{W}$. A more complete description of the Corner Rise trajectories has been given by Richardson (1980b).

\section{The Gulf Stream \\ a. General pattern}

The Gulf Stream can be seen in the buoy trajectories as a band of swift, meandering current which sweeps north and east in a large arc from the Florida Straits to $38^{\circ} \mathrm{N}, 45^{\circ} \mathrm{W}$ (Figs. 1a and $1 \mathrm{~b}$ ). The trajectories indicate the Stream reaches its maximum 


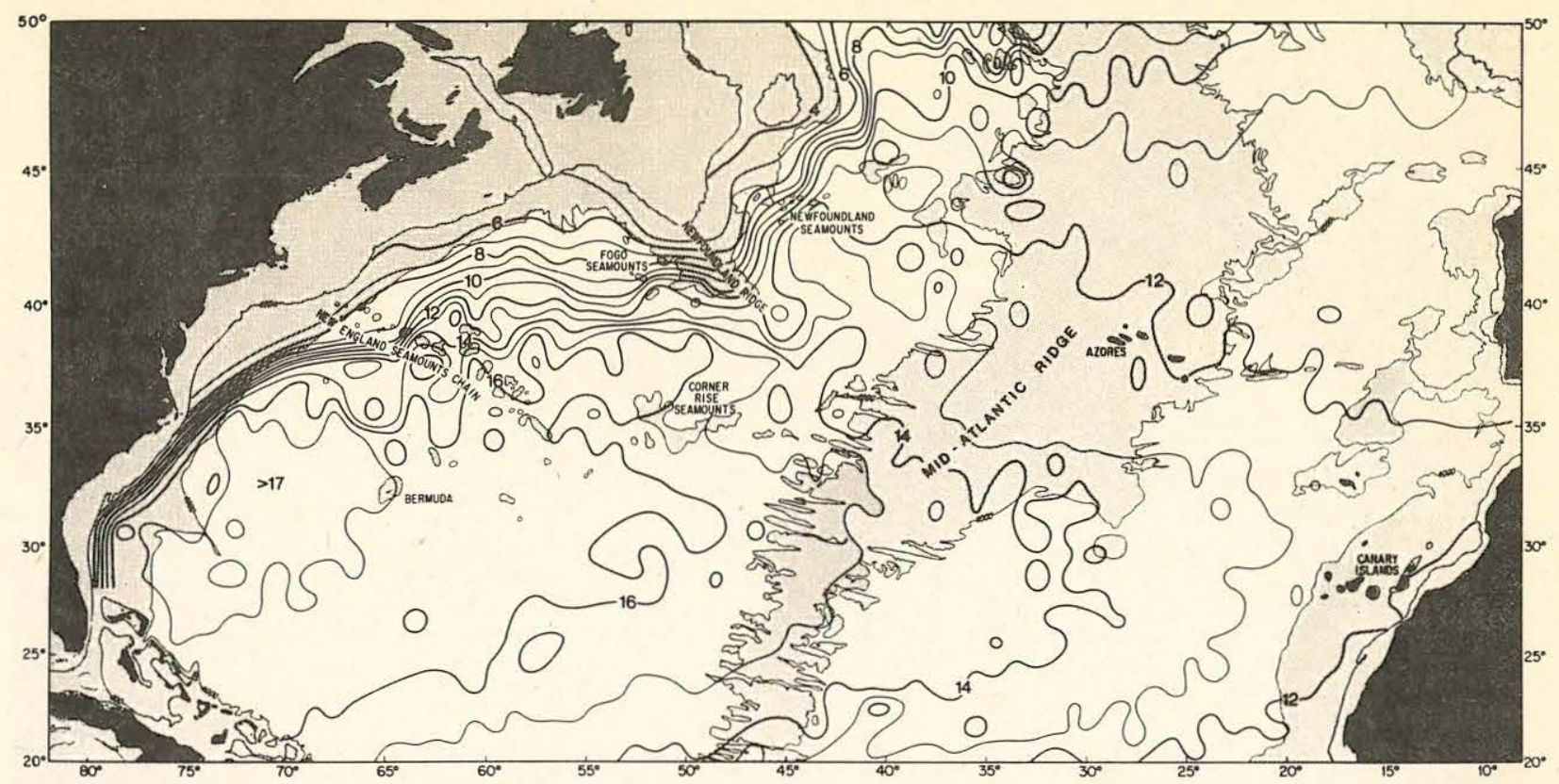

FIG. 2. Mean temperature distribution at a depth of $450 \mathrm{~m}$ based on $1^{\circ}$ square averages of the NODC data. The strong-temperaturegradient region of the Gulf Stream $\left(9-14^{\circ} \mathrm{C}\right)$ is deflected southeastward near the New England Seamounts. The isotherms approach the seamounts in an eastward direction between 37 and $38^{\circ} \mathrm{N}$, curve cyclonically toward the northeast and pass over the seamounts. The northern isotherms $\left(9-11^{\circ} \mathrm{C}\right)$ reach their northernmost point near $41^{\circ} \mathrm{N}, 58^{\circ} \mathrm{W}$ and then dip south again near $54^{\circ} \mathrm{W}$. Eastward of the seamounts there is a marked spreading of isotherms, an indication of the large-amplitude meanders in this region.

latitude between 55 and $60^{\circ} \mathrm{W}$; from there the Stream flows southeastward along the western side of the Newfoundland Ridge which extends southeastward from the Grand Banks. Reaching the area near $38^{\circ} \mathrm{N}, 45^{\circ} \mathrm{W}$, the buoys fanned out in several different directions. Some buoys swung around the Newfoundland Ridge, turned northeastward, and moved across the Mid-Atlantic Ridge north of the Azores. A second group of buoys continued southeastward from the main current on the western side of the Newfoundland Ridge and crossed the Mid-Atlantic Ridge south of the Azores near latitude $33^{\circ} \mathrm{N}$. The two areas in which the buoys moved eastward across the Mid-Atlantic Ridge coincide with two areas of high eddy potential energy density, part of a highenergy region extending eastward from the Gulf Stream (Dantzler, 1977). One of the buoys in the second, southern, branch meandered across the ridge with a relatively high speed, $50 \mathrm{~cm} \mathrm{~s}^{-1}$ against the wind; the trajectory looks similar to many of the trajectories in the Gulf Stream farther to the west. A third group of buoys moved southwestward on the south side of the Gulf Stream, an area of intense mesoscale activity.

West of $60^{\circ} \mathrm{W}$, buoys located outside the Gulf Stream showed a strong tendency to be entrained into the Stream. This occurred for the buoys in rings as well as those in the slope-water region and Sargasso Sea. Once in the Stream the buoys usually moved rapidly eastward to the region south of the
Grand Banks. One-third of the 12 buoys in the Stream that passed over the New England Seamounts looped there for various lengths of time. East of $60^{\circ} \mathrm{W}$ approximately half of the buoys in the Stream moved southward into the region of the Gulf Stream recirculation, and half continued eastward. A few of the buoys stopped their eastward drift as they approached the Mid-Atlantic Ridge, suggesting a possible blocking of the surface currents by the Ridge. It is interesting that none of the buoys moved into the slope-water region north of the Stream, or at least any buoys that did move into the slope water were rapidly entrained into the Gulf Stream again. Peak speeds in the Stream decreased from $\sim 250$ $\mathrm{cm} \mathrm{s}^{-1}$ in the west to $50 \mathrm{~cm} \mathrm{~s}^{-1}$ in the east (Fig. 3). A quantitative analysis of surface currents is in progress.

\section{b. The New England Seamounts}

As the Gulf Stream flows eastward, it crosses over an impressive subsurface mountain chain, the New England Seamounts (Uchupi et al., 1970). These seamounts extend from the continental shelf off Georges Bank near $40^{\circ} \mathrm{N}, 67^{\circ} \mathrm{W}$ southeastward to the Sohm Abyssal Plain near $34^{\circ} \mathrm{N}, 56^{\circ} \mathrm{W}$; they rise $2-3$ $\mathrm{km}$ above the depth of the nearby seafloor and occupy a large portion of the deep water region (Fig. 4). The deep water of the Stream must either be blocked by the seamounts or flow over or through 


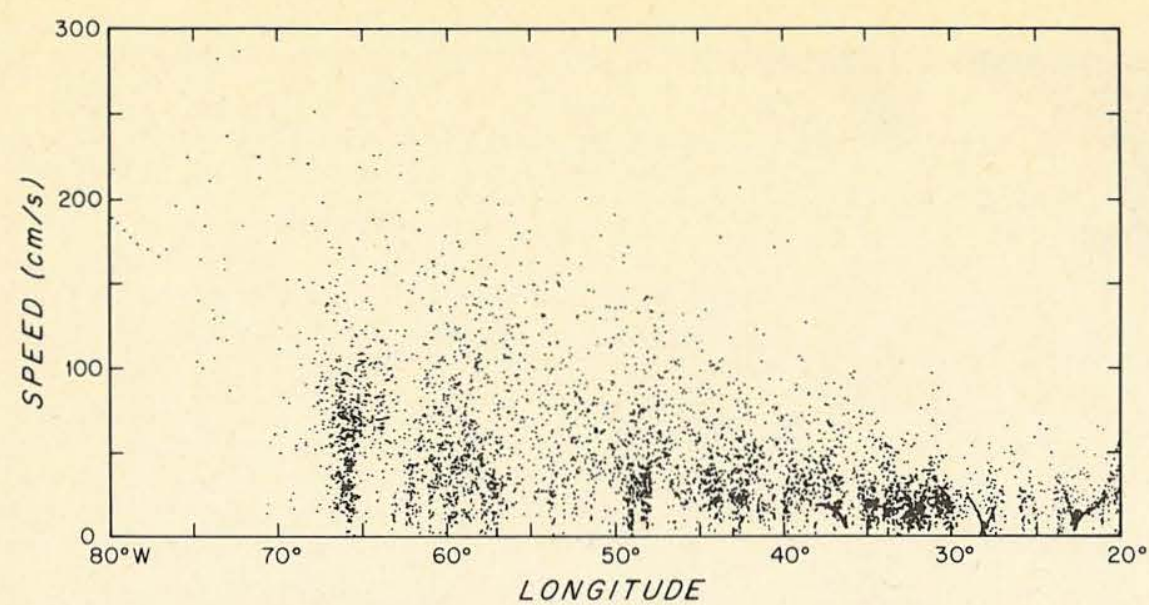

Fig. 3. Speed of 15 buoys in the Gulf Stream region showing a marked decrease in speed with distance eastward. The cluster of speed values near $66^{\circ} \mathrm{W}$ is from a buoy in a ring, and the cluster near $60^{\circ} \mathrm{W}$ occurs where many buoys looped near the New England Seamounts (see Fig. 8). The few anomalously high speeds $\left(>250 \mathrm{~cm} \mathrm{~s}^{-1}\right)$ could have been caused by erroneous fixes.

them. Evidence from the drifting buoys suggests that the influence of the New England Seamounts extends quite strongly to the sea surface where the seamounts cause a deflection of the Gulf Stream and intense mesoscale eddies.

A particularly interesting buoy trajectory and one that clearly shows the eddies near the seamounts is given in Fig. 5. Buoy 1076 approached the seamounts from the west with a speed of $\sim 125$ $\mathrm{cm} \mathrm{s}^{-1}$, slowed to $5 \mathrm{~cm} \mathrm{~s}^{-1}$ as it made an anticyclonic meander over the top of Atlantis II Seamount, and then accelerated as it began to loop near the other seamounts with speeds of $50-80 \mathrm{~cm} \mathrm{~s}^{-1}$. For four months, buoy 1076 looped near the seamounts; some of the loops were small, $20 \mathrm{~km}$ diameter; some were larger, $150 \mathrm{~km}$ diameter. The first large loop was cyclonic, the next three large loops were anticyclonic and had a mean period of 15 days. The next three were cyclonic, similar to cold-core ring trajectories, and had a period of six days. After

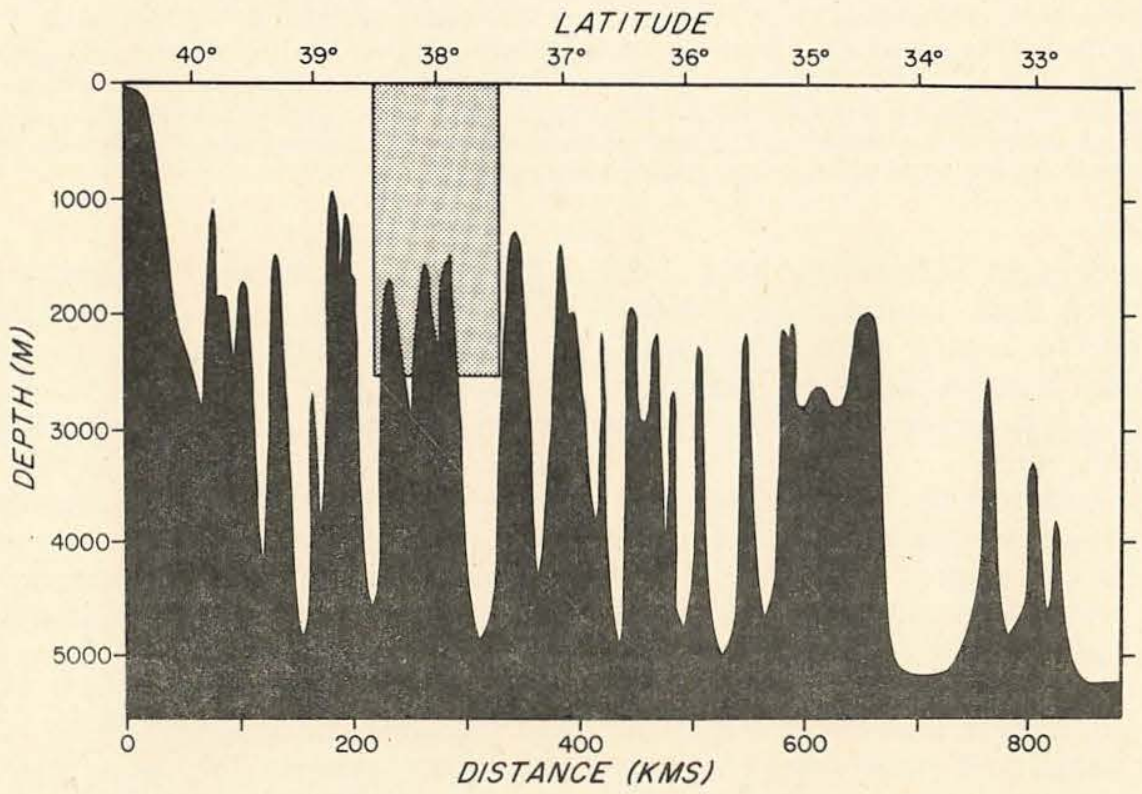

FIG. 4. A north-south section showing the projected depth profile along the New England Seamounts. The Gulf Stream is shown schematically by the stippled region, which is $110 \mathrm{~km}$ wide and $2.5 \mathrm{~km}$ deep. The seamounts extend from Georges Bank southeastward to the Sohm Abyssal Plain near $34^{\circ} \mathrm{N}, 56^{\circ} \mathrm{W}$; thus this projection emphasizes the close spacing of seamounts. 


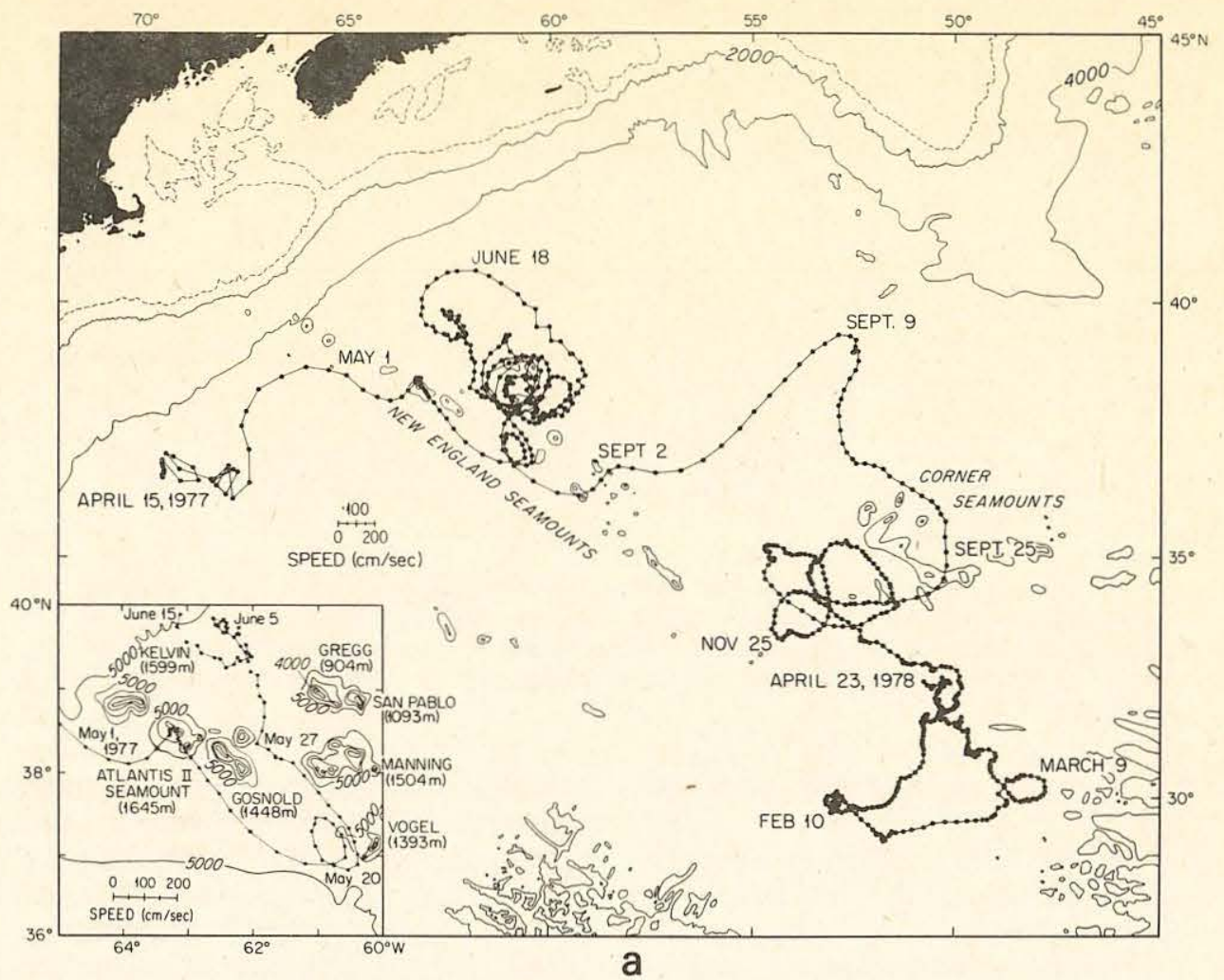

FIG. 5a. Trajectory of buoy 1076, launched near the center of cyclonic Gulf stream ring Bob from 15 April 1977 to 23 April 1978. Two positions per day are shown by dots. This trajectory shows several different types of motion and clearly illustrates the important influence of seamounts on near-surface currents. During April 1977 buoy 1076 looped in ring Bob. At the end of April the buoy was entrained into the Gulf Stream as Bob partially coalesced with the Stream. From May to September, the buoy was trapped in strong eddy motion near the New England Seamounts. In September the buoy continued eastward in the Gulf Stream and from 25 September to 5 December looped in a warm core anticyclonic eddy formed near the Corner Rise Seamounts. During 1978 buoy 1076 drifted rather slowly and aimlessly near $30^{\circ} \mathrm{N}, 50^{\circ} \mathrm{W}$. The inset shows the trajectory of buoy 1076 from 1 May to 15 June 1977 , as it approached the seamounts in the Gulf Stream with a speed of $125 \mathrm{~cm} \mathrm{~s}^{-1}$, slowed to $5 \mathrm{~cm} \mathrm{~s}^{-1}$ as it made a partial anticyclonic loop over the top of Atlantis II Seamount, and then accelerated again as it began its complicated looping motion near some of the other seamounts.

leaving the New England Seamounts, buoy 1076 drifted northeastward, then southward, and looped southwestward of the Corner Rise Seamounts. These loops consisted of small, $20 \mathrm{~km}$ diameter, anticyclonic loops superimposed on larger, $200 \mathrm{~km}$ diameter anticyclonic loops.

As buoy 1076 looped near the New England Seamounts, an unusually good satellite infrared image gave the path of the warm water in the surface Gulf Stream (Fig. 6). An interpretation of the image suggests that the Gulf Stream had formed a large, $350 \mathrm{~km}$ diameter, ring meander located partially over the seamounts, and another meander north of the seamounts. This image and many others (not included) show what appears to be a common feature, a ring meander which extends southward or southeastward near the seamounts. The structure is called a ring meander because it looks like a meander that is in the process of pinching off from the Stream to form a ring (Fuglister, 1972) yet the ring meander seems to remain as a quasi-permanent feature in this region. Whether the ring stays attached to the Stream for long periods of time or whether it repeatedly separates and reattaches is not clear. Several rings have been observed near the seamounts (Fuglister, 1972; Richardson, 1980a) but most of these rings seem to have coalesced with the ring meander; they also may have been formed from the same structure. Earlier observations of the ring meander over the seamounts have been given by Fuglister and Worthington (1951), Fuglister (1963), and Fuglister and Voorhis (1965).

Further evidence for the presence of the ring meander and of strong eddies near the seamounts is given by six buoys, including 1076 (Fig. 7). During the period January-August 1977 there was always at least one buoy looping cyclonically near the seamounts; frequently as one buoy left the ring meander 

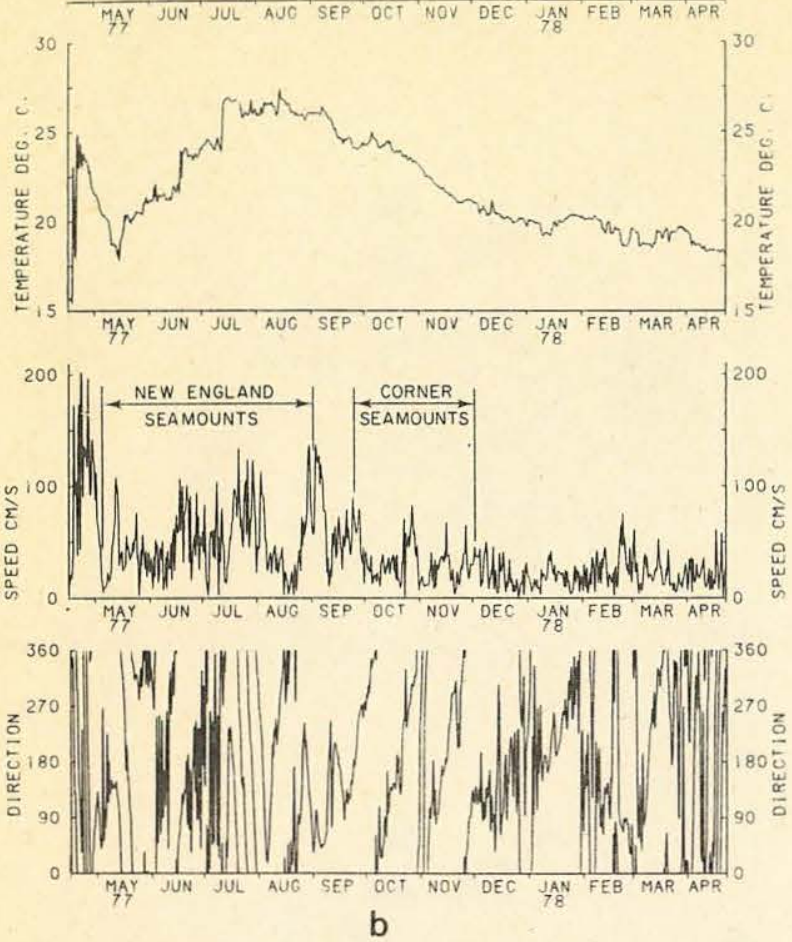

FIG. 5b. Time series for buoy 1076 of temperature, speed and direction.

and stopped looping, another buoy was entrained into the same feature and began to loop $(373,264$, 1076). When the six trajectories are viewed together (Fig. 8) the seamounts stand out as a region $\left(37^{\circ} \mathrm{N}\right.$, $60^{\circ} \mathrm{W}$ ) in which the loops are concentrated. Most, though not all, of the loops are cyclonic and ringlike and they have the following typical characteristics: 3-8 day period, $40-150 \mathrm{~km}$ diameter, and $50-100$ $\mathrm{cm} \mathrm{s}^{-1}$ speeds.

The majority of the buoys in the Gulf Stream passed over the seamounts without looping in mesoscale eddies. ${ }^{2}$ A possible explanation of why these buoys did not show a perceptible local seamountscale deflection when others did is that they were located in the Stream where strong vertical shear insulated the high-speed surface flow from the weaker, deeper perturbed flow (Hogg, 1973). Although the exact trajectories differ, there does seem to be a similarity in their pattern (Fig. 9). The buoys approached the seamounts between 37 and $39^{\circ} \mathrm{N}$, dipped slightly southward, shot northeastward over the seamounts, crested behind them near $59^{\circ} \mathrm{W}$ and dipped south again near $55^{\circ} \mathrm{W}$. As they went over the seamounts, most buoys passed close and northwest of the shallowest of the seamounts, Gregg, which has a minimum depth of $904 \mathrm{~m}$. Three of the buoys $(252,343,1370)$ dropped southward near $59^{\circ} \mathrm{W}$ just after passing the seamounts; these buoys may have been in the northern part of the ring meander structure. East of the seamounts, the latitudinal spread of the trajectories, which extended from 37 to $42^{\circ} \mathrm{N}$, is much greater than the spread

${ }^{2}$ One of these (1040) approached the seamounts at the same time as did two other buoys (215 and 1076), which looped near the seamounts. Buoy 1040 made a large gyre-scale loop, moving southward near $47^{\circ} \mathrm{W}$, westward near $32^{\circ} \mathrm{W}$, and then northward near $58^{\circ} \mathrm{W}$. On reaching the seamounts for the second time, it looped for three months (Fig. 7) and then drifted eastward again.

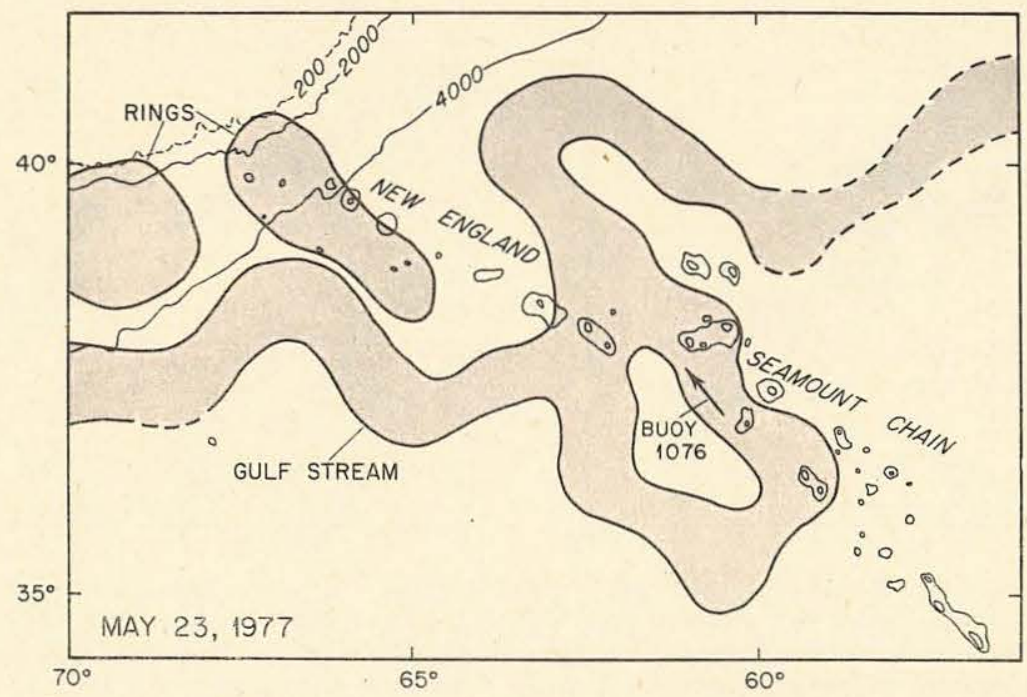

FIG. 6. Interpretation of a NOAA 5 satellite infrared image of the Gulf Stream region, 23 May 1977, as buoy 1076 (speed $45 \mathrm{~cm} \mathrm{~s}^{-1}$ ) began looping near the New England Seamounts. The Gulf Stream formed a large, $350-\mathrm{km}$ diameter ring meander partially overlying the seamounts and another meander north of the seamounts. The total north-south extent of the Gulf Stream near the seamounts is $700 \mathrm{~km}$. 

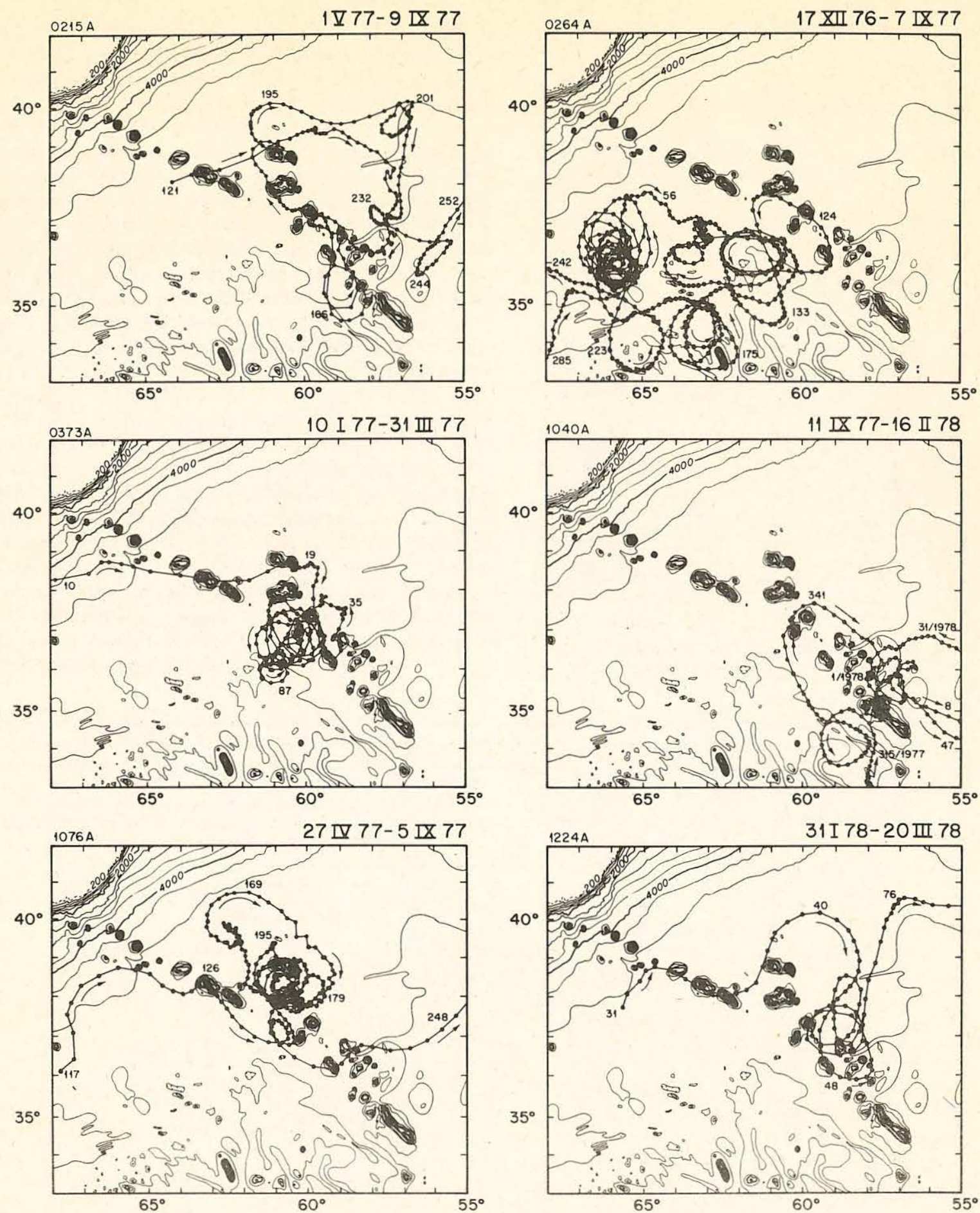

Fig. 7. Trajectories of six buoys which looped near the New England Seamounts during the period December 1976March 1978. The trajectories suggest that a ring-meander frequently occurs near the seamounts; often as one buoy was detrained from the ring-meander another buoy was entrained into it. From January to August 1977 buoys 373, 364 and 1076 successively and almost continuously looped cyclonically in the same ring-meander structure.

west of the seamounts. The patterns observed in these trajectories add evidence to Fuglister's (1963) and Warren's (1963) suggestion that the Gulf Stream makes an abrupt turn to the north near $62^{\circ} \mathrm{W}$ and that this longitude marks a point at which the meander amplitude abruptly increases to the east. 


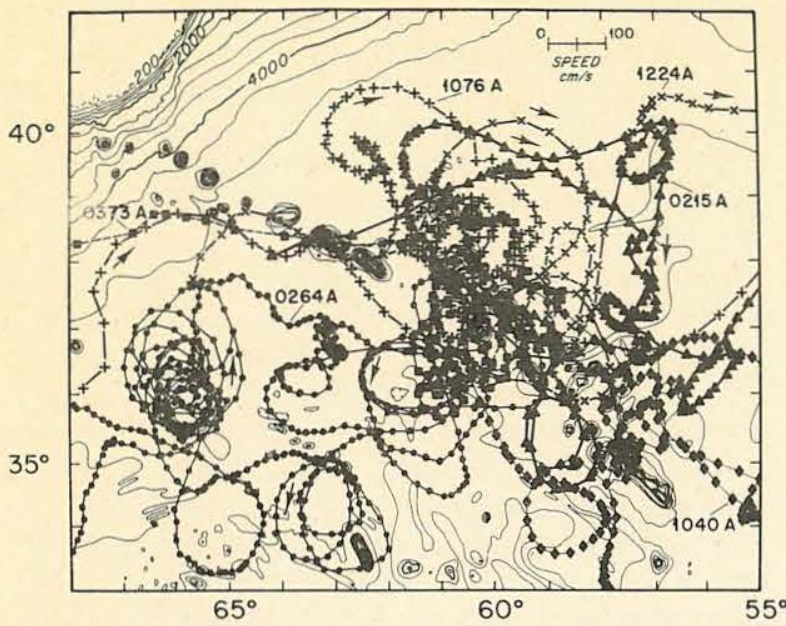

FIG. 8. Superposition of the six trajectories shown in Fig. 7. The New England Seamounts can be seen as an area of intense mesoscale eddies centered near $37^{\circ} \mathrm{N}, 60^{\circ} \mathrm{W}$.

\section{c. Caryn Seamount}

There is evidence that individual, small seamounts can generate eddies in the surface flow. An example of this comes from buoy 1167, which became entrained into the Gulf Stream, moved eastward and passed $50 \mathrm{~km}$ north of Caryn Seamount (Fig. 10). This relatively small seamount rises from a back- ground depth of $4800 \mathrm{~m}$ up to a peak near $2900 \mathrm{~m}$. Just after passing the seamount, the buoy slowed and made two small anticyclonic loops (period 4 days, diameter $25 \mathrm{~km}$ ) before speeding up again and continuing its eastward movement in the Gulf Stream. Perturbed flow near Caryn Seamount has also been observed by T. B. Sanford (personal communication) in velocity profiles; he found anticyclonic vorticity and strong inertial waves located over this seamount. Another example of anticyclonic loops in an otherwise relatively smooth trajectory is given by a buoy that moved eastward in the Kuroshio and spent nearly seven weeks looping in the lee of a seamount in the Emperor Seamount Chain (Cheney et al., 1980).

\section{Mean temperature at a depth of $450 \mathrm{~m}$}

The buoy trajectories show several features in common with the mean $450 \mathrm{~m}$ temperature distribution in the Gulf Stream system (Fig. 2). The temperature map was prepared by calculating the average temperature in each $1^{\circ}$ square. There were typically 50 observations per square, mainly from $450 \mathrm{~m}$ expendable bathythermographs (XBT's).

The Gulf Stream is clearly seen in the west as a region of tightly packed isotherms. The central isotherms in the Stream, $9-14^{\circ} \mathrm{C}$, remain closely

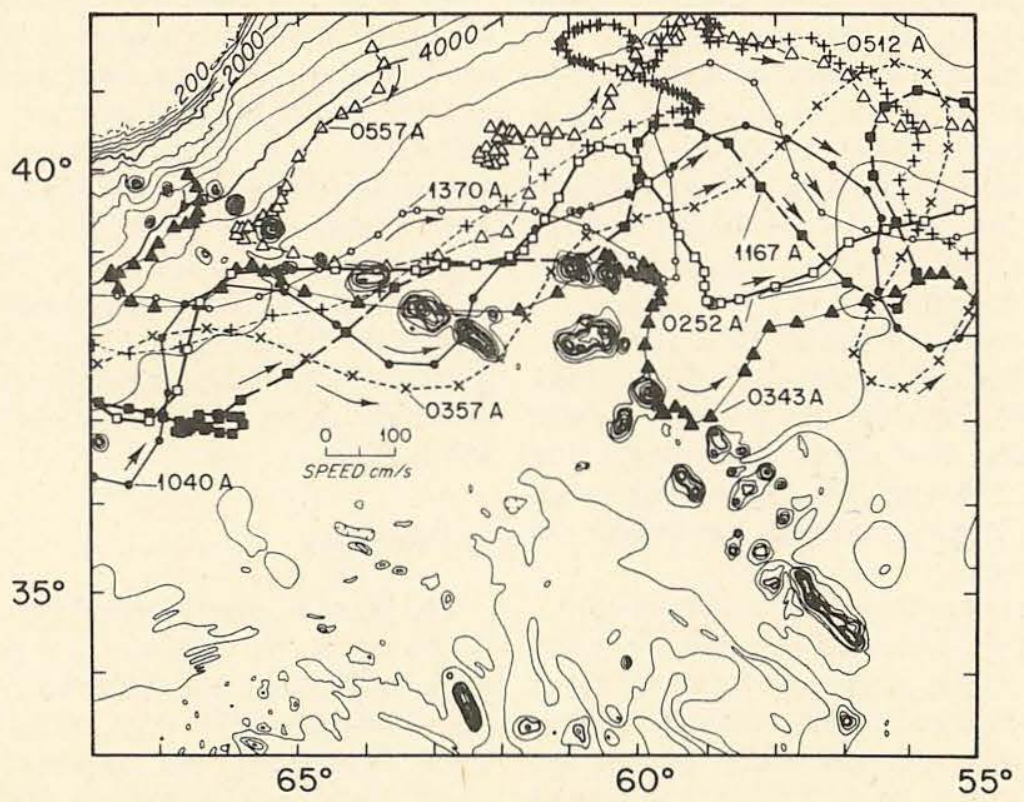

FIG. 9. Trajectories of eight buoys which passed over the New England Seamounts without being caught in strong eddy motion, during the period 30 July 1975 to 20 January 1978. Buoys 343 and 557 were located in the slope water region north of the Gulf Stream but were subsequently entrained into the Stream and moved eastward. These trajectories suggest that the Gulf Stream frequently approaches the seamounts in an eastward direction between 37 and $39^{\circ} \mathrm{N}$; as it passes over the seamounts, the Stream meanders northward cresting near $59^{\circ} \mathrm{W}$ and then south again near $55^{\circ} \mathrm{W}$. East of the seamounts the envelope of trajectories is much wider $(530 \mathrm{~km})$ than west of the seamounts $(220 \mathrm{~km})$. 


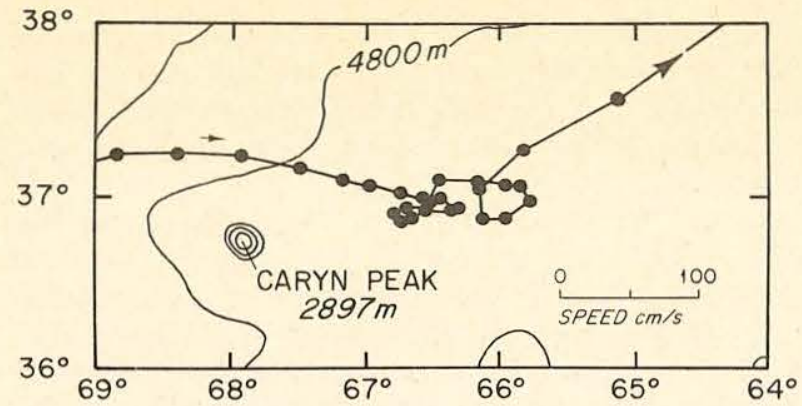

Fig. 10. Trajectory of buoy 1167 from 28 July to 10 August 1976 , as it moved eastward in the Gulf Stream, passed north of the Caryn Seamount, slowed and made two clockwise loops. The loops had a characteristic period of rotation of four days, diameter of $25 \mathrm{~km}$ and speed of $25 \mathrm{~cm} \mathrm{~s}^{-1}$. After the two loops, buoy 1167 accelerated and continued moving eastward in the Gulf Stream. The data for buoy 1167 were provided by A. Leetmaa.

spaced as they arc north and east toward the seamounts. In front of the seamounts the isotherms $\left(10-14^{\circ} \mathrm{C}\right)$ run due eastward; they then make a small southward dip and then change direction to run northeastward over the seamounts much like the buoys (Fig. 9). The northern isotherms $\left(9-10^{\circ} \mathrm{C}\right)$ crest near $58^{\circ} \mathrm{W}$ and then dip southward near $54^{\circ} \mathrm{W}$ in front of Fogo Seamount near $52^{\circ} \mathrm{W}$.

The isotherm pattern indicates that the mean Gulf Stream is deflected $\sim 100 \mathrm{~km}$ southeastward near the line of seamounts. In this case deflection means a shift in position and direction of the isotherms from smooth interpolated curves passing through this region connecting the Gulf Stream west of $70^{\circ} \mathrm{W}$ to the Stream east of $60^{\circ} \mathrm{W}$. It seems probable that in the absence of the seamounts the Gulf Stream would run more nearly parallel to the path shown by the $8^{\circ}$ isotherm. A similar deflection is seen on earlier maps of the mean temperature field at a depth of $200 \mathrm{~m}$ (Fuglister, 1954; Schroeder, 1963).

A significant spreading of the $9-14^{\circ} \mathrm{C}$ isotherms begins at the New England Seamounts. West of the seamounts, the width of the mean Gulf Stream $\left(9-14^{\circ} \mathrm{C}\right)$ is $\sim 100 \mathrm{~km}$; east of the seamounts, the width increases to $350 \mathrm{~km}$. This spreading is an indication of the large-amplitude meanders in this region.

The northern isotherms of the Gulf Stream, $9-11^{\circ} \mathrm{C}$, merge with the $5-8^{\circ} \mathrm{C}$ isotherms to form a second tightly packed region near the Grand Banks. This is partly due to the southward and westward movement of cold Labrador Current water around the Banks. These isotherms pass around the Grand Banks and up to $50^{\circ} \mathrm{N}$ before peeling off in an eastward direction. Only two buoys followed the path of these northern isotherms. The majority of the buoys followed the path of southern isotherms $\left(12-15^{\circ} \mathrm{C}\right)$, which continued eastward until they reached $38^{\circ} \mathrm{N}$, $45^{\circ} \mathrm{W}$ where they rapidly diverged much like the local bottom topography. Near $34^{\circ} \mathrm{N}, 40^{\circ} \mathrm{W}$ the $13-15^{\circ} \mathrm{C}$ isotherms converge toward each other; in this area three buoys moved eastward, one quite rapidly. It should be noted that in this eastern area surface currents are significantly driven by the local wind and can differ from the geostrophic currents indicated by the temperature field.

South of the Gulf Stream is a wedge-shaped area of cold water which projects westward along $35^{\circ} \mathrm{N}$ from near $40^{\circ} \mathrm{W}$ to the New England Seamounts $\left(57^{\circ} \mathrm{W}\right)$. The Gulf Stream recirculation flows southwestward along the north side of this wedge between 35 and $37^{\circ} \mathrm{N}$. On the south side of the wedge is an eastward flowing current which extends across the Atlantic in the latitude band $30-35^{\circ} \mathrm{W}$. The recirculation has been observed with current meters (Schmitz, 1980), ship drift data (U.S.N.O.O., 1978), hydrographic stations (Reid, 1978; Wunsch, 1978) as well as in numerical models of the general circulation (Holland and Lin, 1975; Semtner and Mintz, 1977). The $16^{\circ} \mathrm{C}$ isotherm in this cold wedge almost meets the smaller cold ridge overlying the seamounts, suggesting the presence of a partially closed gyre centered near $37^{\circ} \mathrm{N} 52^{\circ} \mathrm{W}$ that contains relatively high temperatures. Coinciding with this possible gyre, and perhaps another indication of it, is a bare spot on the map of buoy trajectories (Fig. 1). One buoy, 1040, made a large anticyclonic gyre-scale loop around this region.

Extending southward from the Gulf Stream along 65.5 and $73.5^{\circ} \mathrm{W}$ are two relatively cool areas. These are probably due to the large number of XBT's taken in Gulf Stream rings (Fuglister, 1972; 1977; Cheney and Richardson, 1976). Although rings are frequently found in these regions (Parker, 1971; Lai and Richardson, 1977) the calculated mean temperature is probably biased low by $1-2^{\circ} \mathrm{C}$. The cold tongue $\left(11-14^{\circ} \mathrm{C}\right)$ extending southeastward on the north side of the New England Seamounts is near the area in which many buoys looped in the ring-meander and in which three buoys $(252,343,1370)$ meandered southward.

\section{Discussion}

The New England Seamounts seem to disrupt the Gulf Stream. This disruption is manifested as a largescale southeastward deflection of the Stream over the seamounts and large meanders downstream of them. Frequently, the Stream forms a ring meander trapped over the seamounts. A possible explanation of the deflection of the Stream and the largeamplitude meanders is that the Gulf Stream feels the integrated effect of the seamounts as a topographic ridge extending southeastward from the continental shelf off Georges Bank. As the Gulf Stream encounters this ridge, the current is deflected to the 
right (the Stream tries to follow $f / H$ contours). East of the ridge the Stream rebounds northward beginning a pattern of large meanders.

The pattern observed in the buoy trajectories and mean temperature field has much in common with a model of a broad, steady, inertial, eastward-flowing current impinging on a meridional ridge (McCartney, 1976); model streamlines are deflected southward over the ridge reaching a maximum deflection just east of the ridge crest. The streamlines then rebound to the north overshooting and oscillating about their original latitude and forming a stationary Rossby wake downstream of the seamounts. A difference between the model streamline pattern and the measured isotherm pattern is that the maximum isotherm deflection, the area of strong cyclonic curvature, is located just in front of the seamounts. However, this difference may be due to the complexity of the real ocean in comparison to the model. First, unlike the model, the Gulf Stream is a narrow jet exhibiting time-dependent meanders and interacting with a complicated configuration of individual and high seamounts. Second, the mean Gulf Stream approaches the seamount chain obliquely at an angle of about $50^{\circ}$, not perpendicularly. Third, the temperature map is an average of numerous Gulf Stream configurations including meanders and rings.

Individual seamounts also disrupted the Gulf Stream. Several buoys $(215,373,1040,1076,1167)$ made small (seamount-scale) loops downstream from individual seamounts and one buoy, 1076, made a small anticyclonic meander directly over the Atlantis II Seamount. These loops and the meander suggest that individual seamounts generated eddies which at times extended to the ocean surface. Evidence of the deflections and distortions of isotherms near the Atlantis II Seamount, and the existence of warm and cold core eddies in its lee, has been given by Vastano and Warren (1976). The observed trajectories agree with predicted flow patterns in a two-layer model of flow impinging on a circular topographic bump (McCartney, 1975). An upper layer streamline pattern (McCartney, 1975, Fig. 7b) contains an anticyclonic meander over the bump almost identical to buoy 1076's trajectory over the Atlantis II Seamount. In the model the lower layer contains a Taylor column, a region of closed streamlines; the upper layer meander is the surface manifestation of the Taylor column. Downstream of the bump, McCartney (1975, 1976) shows a meandering wake region which, under certain conditions, has cyclonic and anticyclonic eddies embedded in it. One possible explanation for the small observed loops in buoy trajectories is that buoys passing near to seamounts occasionally become entrained into the wake eddies and loop there. A second possible explanation of the small observed loops is that the buoys had become entrained into eddies forced over or downstream of seamounts and had been advected away in the time-varying Gulf Stream current (Huppert and Bryan, 1976). Clusters of seamounts also may act together as broad topographic bumps and be responsible for the larger scale loops seen in the trajectories.

Acknowledgments. This paper is contribution number 4764 from the Woods Hole Oceanographic Institution, and number 162 from the Mid-Ocean Dynamics Experiment (POLYMODE). The research was made possible with funds provided by the National Science Foundation (Grants OCE7818017, OCE77-08045) and the Office of Naval Research (Contract N00014-74-C-0262, NR 083004). E. Kerut, D. Kirwan, A. Leetmaa, and R. Weir generously provided the data from seven of the buoys used in this study. T. McKee, G. Knapp, $\mathrm{J}$. Wheat, and C. Moor assisted with data processing and plotting. Buoy positions were obtained from NASA and satellite images from NOAA-NESS. G. Heimerdinger obtained the temperature data from NODC, D. Haight typed the manuscript, and J. Price gave helpful comments.

\section{REFERENCES}

Cheney, R. E., and P. L. Richardson, 1976: Observed decay of a cyclonic Gulf Stream ring. Deep-Sea Res., 23, 143-155.

_ _ and N. Nagasaka, 1980: Tracking a Kuroshio cold core ring with a free-drifting surface buoy. Deep-Sea Res., 27, 641-654.

Dantzler, H. L., 1977: Potential energy maxima in the tropical and subtropical North Atlantic. J. Phys. Oceanogr., 7, $512-519$.

Fuglister, F. C., 1954: Average temperature and salinity at a depth of $200 \mathrm{~m}$ in the North Atlantic. Tellus, 6, 46-58.

_- 1963: Gulf Stream '60. Progress in Oceanography, Vol. 1, Pergamon Press, 265-283.

, 1972: Cyclonic Gulf Stream rings formed by the Gulf Stream 1965-66. Studies in Physical Oceanography, A Tribute to Georg Wüst on his 80th Birthday, A. L. Gordon, Ed., Gordon and Breach, 137-168.

- 1977: A cyclonic ring formed by the Gulf Stream 1967. A Voyage of Discovery: George Deacon 70th Anniversary Volume, M. V. Angel, Ed. (Suppl. to Deep-Sea Res.), Pergamon Press, 177-198.

, and L. V. Worthington, 1951: Some results of a multiple ship survey of the Gulf Stream. Tellus, 3, 1-14.

- and A. D. Voorhis, 1965: A new method of tracking the Gulf Stream. Alfred C. Redfield 75th Anniversary Volume, Limnol. Oceanogr., 10 (Suppl.), R115-R124.

Hogg, N. G., 1973: On the stratified Taylor column. J. Fluid Mech., 58, 517-537.

Holland, W. R., and L. B. Lin, 1975: On the generation of mesoscale eddies and their contribution to the oceanic general circulation. J. Phys. Oceanogr., 5, 642-657.

Huppert, H. E., and K. Bryan, 1976: Topographically generated eddies. Deep-Sea Res., 23, 655-679.

Kirwan, A. D., Jr., G. McNally and J. Coehlo, 1976: Gulf Stream kinematics inferred from a satellite-tracked drifter. J. Phys. Oceanogr., 6, 750-755. 
Lai, D. Y., and P. L. Richardson, 1977: Distribution and movement of Gulf Stream rings. J. Phys. Oceanogr., 7, 670-683.

McCartney, M. S., 1975: Inertial Taylor columns on a beta plane. J. Fluid Mech., 68, 71-95.

- 1976: The interactions of zonal currents with topography with application to the Southern Ocean. Deep-Sea Res., 23, 413-427.

McNally, G. J., 1981: Satellite tracked drift buoy observations of the near surface flow in the eastern mid-latitude North Pacific. J. Geophys. Res., 86 (in press).

Parker, C. E., 1971: Gulf Stream rings in the Sargasso Sea. Deep-Sea Res., 18, 981-993.

Reid, J. L., 1978: On the mid-depth circulation and salinity field in the North Atlantic Ocean. J. Geophys. Res., 83, 5063-5067.

Richardson, P. L., 1980a: Gulf Stream ring trajectories. J. Phys. Oceanogr., 10, 90-104.

- 1980b: Anticyclonic eddies generated near the Corner Rise Seamounts. J. Mar. Res., 38, 673-686.

— J. J. Wheat and D. Bennett, 1979: Free drifting buoy trajectories in the Gulf Stream system (1975-1978) — data report. Woods Hole Oceanographic Inst. Tech. Rep. 79-4, 159 pp.

Schmitz, W. J., Jr., 1980: Weakly depth-dependent segments of the North Atlantic circulation. J. Mar. Res., 38, 111-133.
Schroeder, E. H., 1963: North Atlantic temperatures at a depth of $200 \mathrm{~m}$. Ser. Atlas of the Marine Environment, Folio 2, Amer. Geogr. Soc., 8 pp. +8 plates.

Semtner, A. J., Jr., and Y. Mintz, 1977: Numerical simulation of the Gulf Stream and mid-ocean eddies. J. Phys. Oceanogr. 7, 208-230.

Uchupi, E., 1971: Bathymetric Atlas of the Atlantic Caribbean and Gulf of Mexico. Woods Hole Oceanographic Institution Tech. Rep. 71-71, 10 charts.

- J. D. Phillips and K. E. Prada, 1970: Origin and structure of the New England Seamount Chain. Deep-Sea Res., 17, 483-494.

U.S. Naval Oceanographic Office, 1978. Surface currents. West central North Atlantic Ocean including east coast of the United States. Naval Oceanographic Office Special Publ. 1400-NA6.

Vastano, A. C., and B. A. Warren, 1976: Perturbations to the Gulf Stream by Atlantis II Seamount. Deep-Sea Res., 23, 681-694.

Warren, B. A., 1963: Topographic influences on the path of the Gulf Stream. Tellus, 15, 167-183.

Wunsch, C., 1978: The North Atlantic general circulation west of $50^{\circ} \mathrm{W}$ determined by inverse methods. Rev. Geophys. Space Phys., 16, 583-620. 
MANDATORY DISTRIBUTION LIST

FOR UNCLASSIFIED TECHNICAL REPORTS, REPRINTS, AND FINAL REPORTS PUBLISHED BY OCEANOGRAPHIC CONTRACTORS

OF THE OCEAN SCIENCE AND TECHNOLOGY DIVISION

OF THE OFFICE OF NAVAL RESEARCH

(REVISED NOVEMBER 1978)

1 Deputy Under Secretary of Defense

(Research and Advanced Technology)

Military Assistant for Environmental Science

Room 30129

Washington, D.C. 20301

Office of Naval Research

800 North Quincy Street

Arlington, VA 22217

3 ATTN: Code 483

1 ATTN: Code 460

2 ATTN: 102B

1 CDR Joe Spigai, (USN)

ONR Representative

Woods Hole Oceanographic Inst.

Woods Hole, MA 02543

Commanding Officer

Naval Research Laboratory

Washington, D.C. 20375

6 ATTN: Library, Code 2627

12 Defense Technical Information Center

Cameron Station

Alexandria, VA 22314

ATTN: DCA

Commander

Naval Oceanographic Office

NSTL Station

Bay St. Louis, MS 39522

ATTN: Code 8100

ATTN: Code 6000

ATTN: Code 3300

1 NODC/NOAA

Code D781

Wiscons in Avenue, N.W.

Washington, D.C. 20235

1 Mr. Michael H. Kelly

Administrative Contracting Officer

Department of the Navy

Office of Naval Research

Eastern/Central Regional Office

Building 114, Section D

666 Summer Street

Boston, MA 02210 
UNCLASSIFIED 10/81

SECURITY CLASSIFICATION OF THIS PAGE (When Data Entored)

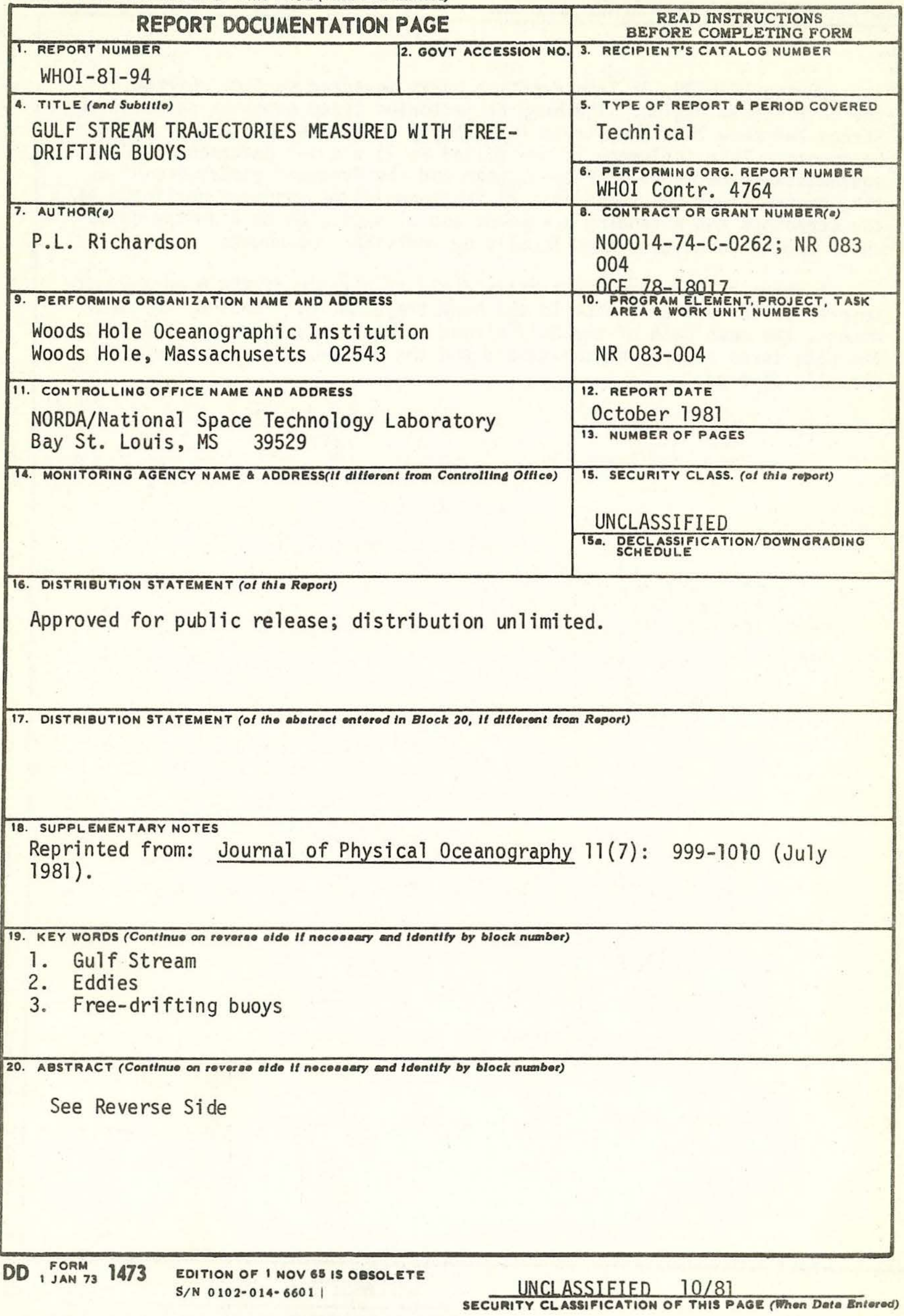


20.

During 1975-78, 35 free-drifting buoys measured surface currents in the Gulf Stream region. The buoy trajectories trace numerous paths of the Stream and show that the Stream is strongly influenced by the New England Seamounts. This influence is manifested as 1) a quasi-permanent, $100 \mathrm{~km}$, southeastward deflection of the Stream and the frequent occurrence of a ring meander over the seamounts; 2) large-amplitude meanders beginning at the seamounts and extending eastward; and 3) small, $20 \mathrm{~km}$ diameter eddies which appear to be generated locally by individual seamounts.

A chart of the mean temperature field at a depth of $450 \mathrm{~m}$ agrees with several of the patterns seen in the buoy trajectories. West of the seamounts, the mean path of the Gulf Stream is eastward; over the seamounts, the path turns sharply northeastward and the isotherms in the Stream abruptly diverge. 


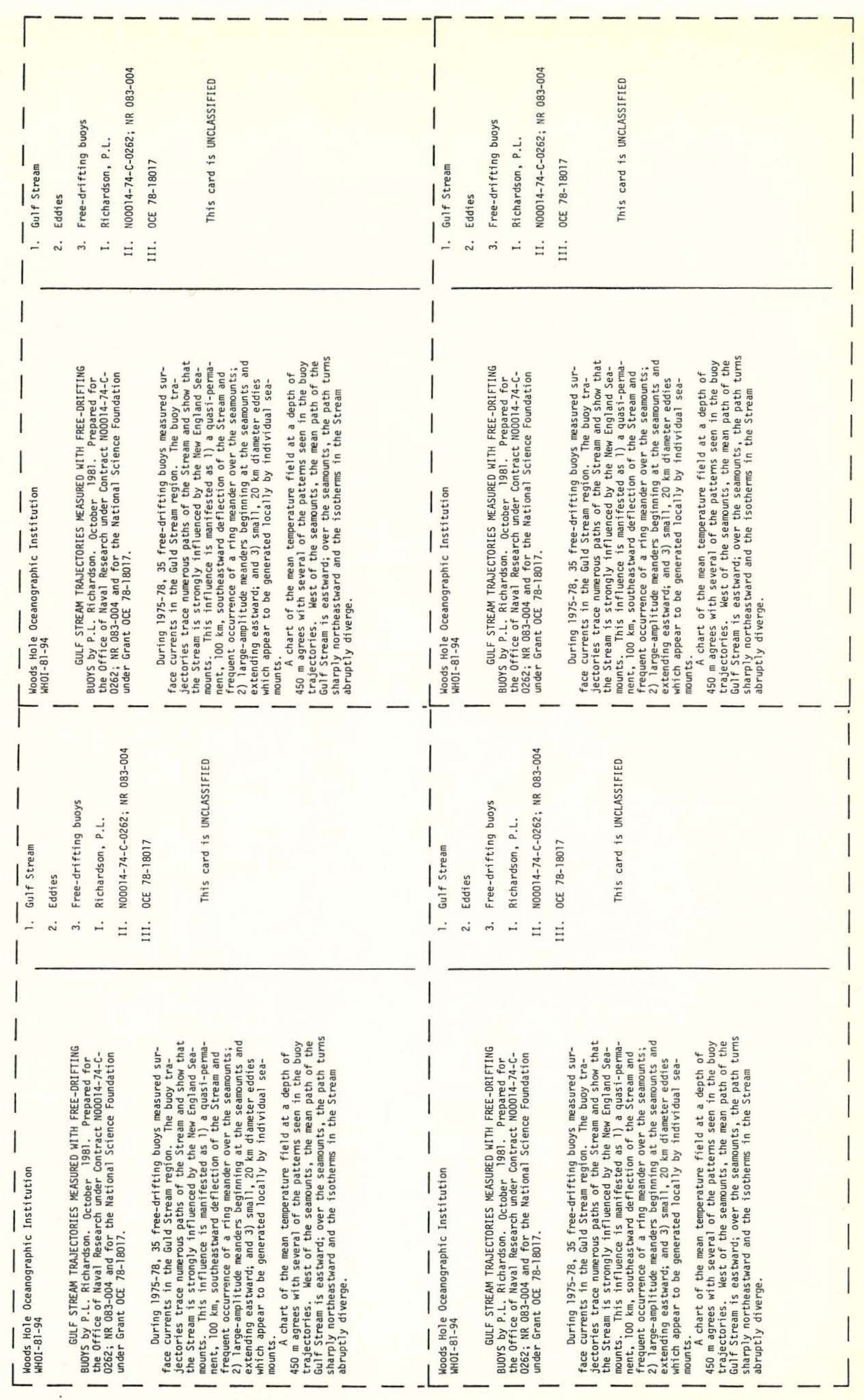

